\title{
A GAZDASÁGI SZEREPLÖK HATÁRON ÁTNYÚLÓ TEVÉKENYSÉGE
}

\author{
(Cross-Border Activities in Business)
}

\section{GROSZ ANDRÁS - TILINGER ATTILA}

\begin{abstract}
Kulcsszavak:
határtérség határon átnyúló együttmüködés vállalkozások gazdasági kapcsolatok szlovákmagyar

A tanulmány legfontosabb célja a gazdasági szereplök szlovák-magyar határtérségben való interakcióinak feltárása. A határtérségek területi különbségein és a külföldi müködōtöke beruházásoknak köszönhető gazdasági fejlódésen túl a szomszédos országban való cégalapitás lehetôségei is a vizsgálat tárgyát képezik. A szerzỏk megvizsgálják az intézményi-gazdasági szereplök közötti egyiuttmüködés mértékét, mélységét, és arra keresik a választ, hogy a két oldal mennyire integrálódott egymással. Végül a kutatás arra is fényt derit, hogy a befektetési kedv folyamatos növekedése a határon átnyúló gazdasági mozgások felélénküllésében is tükrözödik, melyet az intézményi-vállalati szintü fejlesztések egyértelmüen dinamizálnak. A határon átmyúló egyuittmüködési kapcsolatokban a 2004-es EU-csatlakozás egyértelmüen jelentós fordulópont volt, mig a Schengeni tagság nem hozott érzékelhetỏ változásokat. A jövöben komoly hatása lehet az euró bevezetésének, különösen a két ország közötti időbeli különbségnek a gazdasági integrációs folyamatokra.
\end{abstract}

\section{Bevezetés}

Jelen tanulmány célja, hogy megpróbálja feltárni a határon átnyúló gazdasági kapcsolatokat, együttmükődési irányokat a szlovák-magyar határ vonatkozásában. A legfontosabb kutatói kérdések, amelyek a vizsgálatainkat vezették a következỏk voltak: Milyen mértékben, mélységben sikerült integrálódnia a két határtérség gazdaságának egymással? Mely térségekben alakultak ki egybefüggó határrégiók, illetve milyen akadályai tapasztalhatók az integrációnak? A határ egyik oldalán lévő gazdasági szereplő milyen mértékben használja a határ túloldalát, és erre milyen igényei, lehetőségei vannak? Milyen típusú fejlesztési eszközökkel, beavatkozásokkal lehetséges az integrálódási folyamat elósegítése, gyorsítása? Munkánkat természetesen részben a témával foglalkozó korábbi szakirodalom feldolgozásával kezdtük, de fő irảnyát elsősorban a határtérségben múködő különböző gazdaságfejlesztéssel, vállalkozásfejlesztéssel foglalkozó szervezetek (kereskedelmi és iparkamarák, vállalkozásfejlesztési alapítvánnyok, inkubátorházak és egyéb intézmények) vezetôivel, illetve nemzetközi kapcsolatokért felelős munkatársukkal folytatott személyes interjúk képezik. Az interjúk felépítése általában a következő struktúrát követte: 1) az intézménynek a szlovák-magyar határtérséghez viszonyuló általános helyzetképének megismerése; 2) a Magyarországon mủködő szlovák vállalkozások, valamint a Szlovákiában múködő magyar vállalkozások tevékenységének feltárása; 3) az integrálódási folyamatot ösztönző fejlesztések realitása mind intézményi, 
Grosz András - Tilinger Attila: A gazdasági szereplök határon átnyúló tevékenysége.

Tér és Társadalom, 22. 2008. 3. 81-96. p.

82 Grosz András - Tilinger Attila

TÉT XXII. évf. 2008

mind vállalati szinten. Természetesen a két ország rendszerváltás utáni történelmét figyelembe véve mindezeket megpróbáljuk egy időbeli síkban elhelyezni.

Természetesen számos korábbi munka született már a térség gazdaságával kapcsolatban. Mindazonáltal a dél-szlovákiai térség gazdasági szerkezetének átalakulásával, integrálódásával és versenyképességével foglalkozó müvek esetében a határon átnyúló gazdasági kapcsolatok vagy egyáltalán nem jelennek meg, vagy csak nagyon korlátozottan (Lelkes 2003; 2008; Ádám 2004; 2005; Hováth 2004; Morvay 2004; Réti 2004a; 2004b; 2005). A hazai oldalon inkább a határ menti térség egyegy szakaszára koncentrálnak ezek a munkák (pl. A Kárpát-medence régió sorozatban megjelent eddigi monográfiák: Beluszky 2007, Rechnitzer 2007). A határon átnyúló gazdasági kapcsolatok vizsgálata sok esetben nem a teljes határszakaszra (pl. Reiter-Semsey-Tóth 2004), hanem annak csak egy, szükebb a tényleges üzleti kapcsolatok által generált igények mentén meghatározott részére fókuszálnak (Györ-Moson-Sopron megyében... 2000; Cégkatalógus... 2005; A határ menti vállalkozások... 2006; Helyzetkép... 2006). Viszonylag szűk tehát azon irodalmak köre, amelyek a szlovák-magyar határ menti térség határon átnyúló gazdasági folyamatait is megpróbálják feltárni (Réti 1999; Ádám 2003; Lelkes 2005).

\section{Gazdasági szerkezetváltás a két országban}

Bár a két országban a rendszerváltás és az Európai Unióhoz történő csatlakozás is egy időpontban történt, Magyarország és Szlovákia gazdasági folyamatait illetően eltérő fejlödési pályáknak lehetünk tanúi. Míg a kilencvenes évek végéig egyértelmủen hazánk számított a közép-európai országok közül a gazdasági szerkezetváltás terén is az egyik legfontosabb mintatanulónak, addig az elmúlt évek egyre nyomasztóbb makrogazdasági problémái okán mind több vonatkozásban találkozhatunk hazánkkal, mint az egyik legproblémásabb országgal (infláció, államháztartási hiány, államadósság, az euró várható bevezetése...). Ezzel szemben Szlovákia a Csehországtól való 1993-as szétválása után energiáit elsősorban saját identitásának keresésére és politikai stabilitásának biztosítására fordította. 1998-tól azonban, még inkább a 2000-es évektől kifejezetten befektetőbarát vállalkozói környezet kialakításával kívánja ledolgozni a többi KKE-i országtól való gazdasági lemaradását. Utóbbit oly sikeresen, hogy mára egyértelmüen a nemzetközi szervezetek „bezzeg” országává vált (óriási gazdasági növekedés, hatalmas külföldi müködőtőke befektetések, stabil makrogazdasági környezet és az euró várható 2009-es bevezetése).

Mindkét ország esetében rendkívül fontos szerepet kapott a gazdasági szerkezetváltásban és a gazdaság versenyképességének javításában a külföldi müködőtőke és az általuk meghonosított új technológiák, szektorok, legyen szó akár a privatizáció eredményeként, akár új zöldmezös beruházásként megvalósított befektetésekről. A gazdasági növekedés egyértelmủ motorja a külföldi beruházásoknak köszönhető exportorientációjú feldolgozóipar (különösen a jármüiparban és az elektronikai iparban). Elsősorban hazánk politikai és gazdasági stabilitásának köszönhetően Ma- 
Grosz András - Tilinger Attila: A gazdasági szereplök határon átnyúló tevékenysége.

Tér és Társadalom, 22. 2008. 3. 81-96. p.

gyarország a kilencvenes évek végéig KKE-ban élen járt a külföldi müködötőke vonzásban. Ezzel szemben Szlovákiában a külföldi befektetések kezdetben csak rendkívül korlátozottan jelentek meg, elsősorban a kedvezőtlen politika környezetnek köszönhetően, azonban az 1990-es évek végén bekövetkezett politikai irányváltás és gazdaságpolitikai koncepcióváltás hatására a tőkebeáramlás hihetetlen mértékben felgyorsult.

Ennek következtében hazánk gazdasági stabilitása, makrogazdasági mutatói az 1990-es évek közepéig-végéig, elsősorban a külföldi tőkebeármalásnak köszönhetö exportvezérelt feldolgozóipar termelékenységének és versenyképességének javulása miatt egyértelmủen kedvezőbbek voltak. Az elmúlt években tapasztalható hihetetlen dinamikát (8-10\%-os GDP bỏvülés) produkáló szlovák fejlődéssel kapcsolatban sokszor hallani az egykulcsos adórendszer jótékony hatásáról és gazdaságélénkítö szerepérỏl. A valóságban azonban látni kell, hogy az sokkal inkább köszönhetó a nagy külföldi befektetöi boomnak, különösen a gazdaság szerkezetében meghatározó autóiparnak és az ahhoz kapcsoldó beszállító háttériparnak. Szlovákiát a három nagy autógyár (Volswagen, Hyundai-Kia, Peugeot-Citroen) letelepedésének és termelésük felfutásának köszönhetően ma már egyre többen kelet-közép-európai Detroitkẻnt emlegetik, és korábbi elemzések 2007-re az autóiparnak a teljes kivitelhez való hozzájárulását 40-45\%-ra becsülték (Tornay 2004). A teljes ipari termelés egyötödét és a kivitel negyedét a három szlovákiai autogyár adja. Ezek a nagy multinacionális cégek, csakúgy, mint az elektronikai ipar terén mủködők többsége is, még a mára sok helyen példaértékủnek tekintett egykulcsos adóreform bevezetése elött döntöttek szlovákiai beruházásaikról, elsősorban az alacsony termelési költségek, a vállalkozásbarát kormányzati politika és az állami támogatások, kedvezmények hatására (Új csodafegyvere... 2008). Az interjúink során megkérdezett szakértők közül többen azt mondták, hogy tulajdonképpen Szlovákia gazdasága 5-10 éves késéssel reprodukálja a magyarországi folyamatokat, amennyiben elsősorban a költséghatékonyságra építő, viszonylag alacsony hozzáadott értékü tevékenységek letelepítésével járó külöföldi tőkebefektetéseket és egyértelmủen az extenzív iparfejlesztés sajátosságait vizsgáljuk. Jóval rosszabb a helyzet például Szlovákiában, ha az egyébként hazánkban sem túlságosan magas $\mathrm{K}+\mathrm{F}$ ráfordításokat vizsgáljuk. Míg Magyarországon 2006-ban éppen a GDP 1\%-át tette ki, addig Szlovákiában a fél \%-ot sem érte el, ráadásul a hazainál még alacsonyabb az üzleti szféra által finanszírozott kutatás-fejlesztés.

Mindazonáltal ezen késői fejlődés eredményekẻnt Szlovákia a gazdaságitársadalmi fejlettséget legjobban reprezentáló egy före jutó GDP tekintetében 2006-ban már utolérte Magyarországot, a 2007-re vonatkozó becsléseket figyelembe véve pedig már meg is előzte hazánkat, nem beszélve a várható 2008-as folyamatokról, amelyek az elörejelzések szerint már igen komoly különbségekhez vezetnek (1.ábra). Míg 1997-ben még szinte azonos szinten állt a két ország az EU27 átlagához viszonyítva (alig meghaladva annak 50\%-át), addig a 2003-ban megmutatkozó legnagyobb (közel 8 százalékpontos) különbség három év alatt ledolgozásra került, az idén pedig már majdnem hasonló mértékủ különbség várható, de Szlovákia javára. 
Grosz András - Tilinger Attila: A gazdasági szereplök határon átnyúló tevékenysége.

Tér és Társadalom, 22. 2008. 3. 81-96. p.

Ugyanezen folyamatok figyelhetök meg a termelékenység alakulásában is, és mảra már az átlagfizetés vásárlóerejében is beérte hazánkat északi szomszédunk a 2002-es több mint 10 százalékpontos különbség ellenére (Új csodafegyvere... 2008) (2. ábra).

\section{1. ÁBRA}

$A$ vásárlóerö-paritáson számitott egy fơre jutó $G D P$

és a termelékenység alakulása, 1997-2008 (EU27=100)

(Development of GDP per Capita in PPP and Productivity)

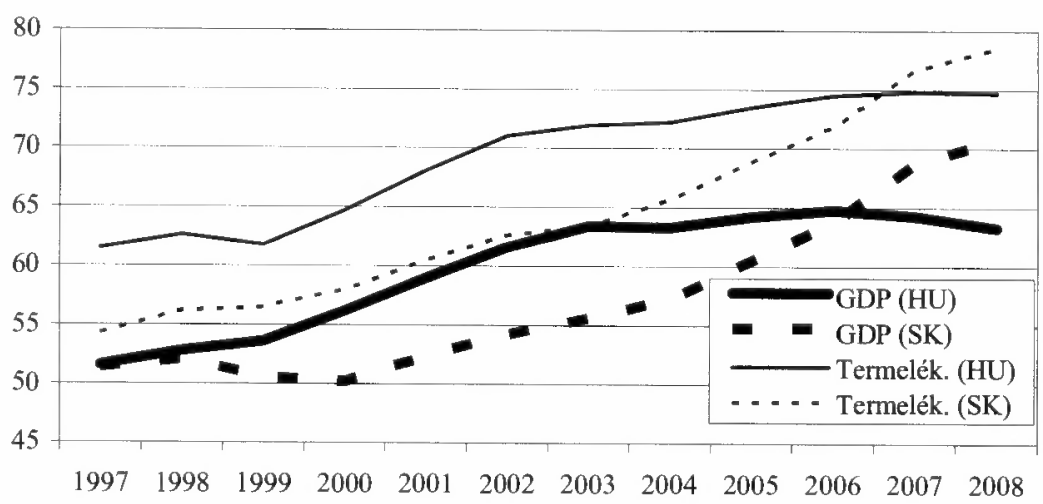

* Termelékenység: egy foglalkoztatottra jutó GDP vásárlóerö-paritáson.

** A 2007-2008 évekre vonatkozó adatok csak elörejelzések.

Forrás: KSH alapján saját szerkesztés.

\section{2. ÁBRA}

Az összehasonlitó árszintek alakulása, 1995-2006 (EU27=100)

(Development of Prices in Purchasing Power Parity)

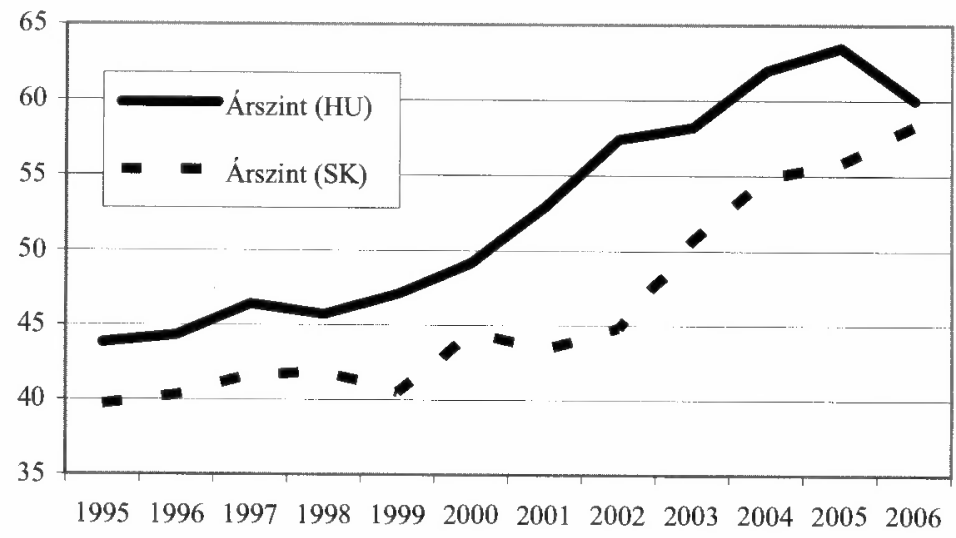

*A háztartások fogyasztásának közvetett adókat tartalmazó összehasonlító árszintjei.

Forrás: KSH alapján saját szerkesztés. 
Grosz András - Tilinger Attila: A gazdasági szereplök határon átnyúló tevékenysége.

Tér és Társadalom, 22. 2008. 3. 81-96. p.

A gazdasági szereplök határon ...

\section{Területi különbségek a határtérségben}

Akár a magyarországi vagy a szlovákiai, akár pedig a közös határtérséget vizsgáljuk, a gazdasági szerkezetváltás lefolyásában és a gazdasági-társadalmi fejlettség terén igen komoly területi különbségeknek lehetünk tanúi. Magyarországon egyértelmủen a fơváros, Budapest és agglomerációja a rendszerváltást követő időszak legnagyobb nyertese, illetve a Közép-magyarországi régió mellett az ország nyugati határ menti térsége, valamint az észak-dunántúli térség (a Bécs-Budapest közötti közlekedési tengely mentén) (Rechnitzer-Smahó 2006). E térségek voltak a külföldi müködőtőke letelepedésének elsőszámú célpontjai, és itt zajlott le a leggyorsabban a gazdasági szerkezetváltás. Ezzel szemben a magyarországi fejlődési dinamika az ország többi területén (Északkelet-Magyarország, Dél-Magyarország) sokkal korlátozottabban volt csak érzékelhető, bár az elmúlt években már tapasztalható a keleti autópályák továbbépítésének kedvező hatása. De mindenképpen kiemelendő, hogy ha a szlovák-magyar határ menti térséget nézzük, akkor a magyar oldalon GyőrMoson-Sopron, Komárom-Esztergom és Pest megye, valamint Budapest az ország legfejlettebb, legdinamikusabb és legversenyképesebb térségei. Az Ipolytól keletre Nógrád és Borsod-Abaúj-Zemlén megyék gazdasága, mely korábban a tradicionális nehézipar kiemelkedö központjainak adott helyett, nagyon sokáig az ipari válságtérségek jegyeit mutatta, és még csak most kezdenek el kilábalni ezekből a problémákból, de sok szempontból még ma is periférikus sajátosságúak.

Az 1990-es rendszerváltás természetesen Szlovákiában is jelentős hatással volt a gazdasági szerkezetváltásra és ezáltal Dél-Szlovákia gazdasági folyamatainak formálására. A gazdasági ágak közötti átrendeződésnek köszönhetően a tercier szféra vált a legfontosabb ágazattá, melynek súlya a foglalkoztatásban 2000-re megközelítette a $60 \%$-ot, miközben az ipar részesedése továbbra is $30 \%$ körül alakult ( $\mathrm{Ba}$ logh-Gulyás-Nagy 2004). Az 1990-es évek végétől országos szinten egyértelmủen megfigyelhető gazdasági növekedés ellenére a dél-szlovák területekre inkább a gazdasági stagnálás a jellemző, mely igen határozott nyugat-kelet fejlettségi lejtővel párosul (Lelkes-Szalay 2004). A Szlovákiába érkező külföldi mưködőtőke a mai napig erőteljes területi koncentrációt mutat, melyben meghatározó Pozsony szerepe (Balogh-Gulyás-Nagy 2004). A föváros mellett kiemelendő még Kassa és az ország nyugati területei (Nagyszombati, Trencsényi és Zsolnai kerületek), melyek többek között ennek is köszönhetöen jóval kedvezöbb társadalmi-gazdasági helyzetben vannak, mint a dél-szlovákiai medencében és a kelet-szlovákiai térség, ahol egyértelmủen a válság és a depresszió jelei mutatkoznak (Lelkes-Szalay 2004). Tehát a fejlett ipar betelepülése csak Nyugat-Szlovákiára jellemzö, keleten továbbra is óriási a munkanélküliség és nagy a szegénység (Új csodafegyvere... 2008). A keleti országrészben a határon átnyúló gazdasági kapcsolatok, együttmúködések gazdaságélénkítő szerepe is problematikus, hisz a határ másik oldalán éppolyan periférikus, vagy válsággal küzdő terület található. Dél-Szlovákia kedvezőtlen pozícióját mutatja, hogy a teljes ipari termeléshez mindössze 12,2\%-kal járul hozzá, és járásait 
tekintve mindössze négy sorolható az erősen iparosodottak közé (egyikük sem határos közvetlenül Magyarországgal), míg a többi 13 csak gyengén iparosodott (Balogh-Gulyás-Nagy 2004).

Tehát, ha a határ térséget vizsgáljuk, elmondható, hogy annak nyugati területein egyértelmủen egyfajta kettősség tapasztalható: fejlett Pozsony, fejlett iparral rendelkező Észak-Dunántúl és Budapest áll szemben a kevésbé prosperáló és inkább stagnáló dél-szlovákiai medencével (ennek következtében a munkaerö-piaci mozgások egyértelmủen Szlovákia-Magyarország irányúak). Ezzel szemben a határtérség keleti felén sokkal kisebbek a különbségek a két oldal között, köszönhetően annak, hogy a határ mindkét oldalának gazdasága kevésbé fejlett, a gazdasági szerkezetváltás még nem fejeződött be, és egyaránt tetten a érhetök periférikus elhelyezkedésböl fakadó hátrányok. Irányát tekintve talán a nyugatival ellentétes, inkább a szlovák oldal felé történő mozgások válhatnak a közeljövöben erösebbé Kassa-Miskolc vonatkozásában, köszönhetỏen elöbbi komoly regionális központi pozíciójának. Mindazonáltal megállapítható, hogy a határ menti térség viszonylag kis népességet és a határ menti kapcsolatok a gazdasági szereplők még kisebb csoportját érintik.

\section{A külföldi müködötöke beruházások}

A határon átnyúló élő gazdasági kapcsolatok, gazdasági aktivitás egyik legjelentỏsebb mutatója a külföldi mủködötőke-befektetés, azaz a szomszédos országban történö új cég alapítása, illetve leányvállalat létrehozása. A vállalkozók viszont csak abban az esetben élnek ezzel a lehetőséggel, ha valamilyen potenciált, új kihívásokat látnak a határ túloldalán. Egy profitorientált cégnek mérlegelnie kell az alapításhoz kapcsolódó elönyöket és hátrányokat, illetve számba kell vennie az országok közötti eltérỏ gazdasági, pénzügyi és jogi környezetet.

Miért érdemes Magyarországot vagy Szlovákiát választania a külföldi müködötökének, különösen az autóipar területén? Milyen közvetlen vagy közvetett gazdasági, költség, termelékenységi, értékesítési, logisztikai stb. előnyökben, valamint állami támogatásokban, kedvezményekben részesülhetnek a beruházások, amelyek akár döntőek is lehetnek egy-egy döntés meghozatala során. A földrajzi közelség, a gazdasági-társadalmi folyamatok részben közös történelme miatt sok esetben szinte alig tehetünk különbséget a két ország között, a telephelyválasztás szempontjából egyre inkább kezd egy viszonylag egységes, nagyobb gazdasági térként viselkedni a térség. Ugyanakkor természetesen, különösen az állami szerepvállalás, a speciális kedvezmények és támogatások területén, valamint a gazdasági tevékenységre közvetlenül ható lokális környezet minősége tekintetében különbségek fedezhetők fel, nem csak az egyes országok között, hanem azok különböző fejlettségủ térségei között is. Emellett legalább ilyen hatása van az egyes országok makrogazdasági és politikai stabilitása folyamatos változásának az elmúlt két évtizedben. Viszonylag magas azon elónyök száma, amelyek tulajdonképpen mindkét ország esetében megfigyelhetỏk, vagy legalábbis, mindkét ország szeretné saját magának tudni azokat: 
Grosz András - Tilinger Attila: A gazdasági szereplök határon átnyúló tevékenysége.

Tér és Társadalom, 22. 2008. 3. 81-96. p.

- EU-tagság és annak előnyei, nagy potenciálisan elérhető piac;

- hosszú távú politikai stabilitás, mint biztonságos befektetési környezet;

- EU konform kormányzati befektetés-ösztönző politika;

- kedvezỏ munkaerőköltség és magas termelékenység/bér arány;

- magasan képzett, kreatív és rugalmas munkaerö;

- magasan fejlett, illetve folyamatosan kiépülö közlekedési és kommunikációs infrastruktúra (az ország bizonyos részeiben csak);

- vállalkozásbarát környezet, liberális szabályozás (inkább Szlovákiára jellemző);

- stabil gazdasági helyzet és dinamikus gazdasági növekedés (utóbbi években szintén inkább csak Szlovákiára jellemző).

Szlovákiában ugyanakkor inkább a logisztikai adottságokra, folyamatos infrastrukturális fejlesztésekre és természetesen a mindenki által ismert és sokat hivatkozott speciális adórendszer kínálta kedvező lehetőségekre helyezik a hangsúlyt.

\section{A cégalapitás lehetöségei Szlovákiában}

Szlovákiában 2004. január elsejével bevezették az egykulcsos adórendszert, ami azt jelenti, hogy minden adó - többek között a társasági adó mértéke is - egységesen $19 \%$. A politikai szereplők e döntésével nemcsak a szlovák gazdasági környezet vált sokkal versenyképessebbé, hanem a feketegazdaságot visszaszorító hatása is jelentősnek bizonyul. Magyarországon a társasági adó mértéke általános esetben igaz kevesebb, $16 \%$, viszont a rendszert meglehetósen bonyolítják a különböző mértékú kedvezmények és plusz adóterhek. A két állam teljes mértékben eltérö adórendszere az országok közötti gazdasági mozgásokat jelentős mértékben felerősíthetik. Mindezekből arra a következtetésre jutunk, hogy a legföbb ok, amiért érdemes egy magyar vállalkozásnak befektetnie Szlovákiában nem más, mint a kedvezőbb adórendszer.

A jobb gazdasági környezet viszont nemcsak az egyszerủsített és átláthatóbb adózási szisztémát jelenti, hanem magában foglalja az egyszerúbb jogi környezetet, az egyszerübb cégalapítási feltételeket és az alacsonyabb adminisztrációs, jảrulékos költségeket (pl. az ügyvédi dijat) is. A vállalkozók gyakran élnek azzal a lehetőséggel, hogy telephelyüket a jobb adózási feltételek kihasználása végett teszik át a szomszédos országba. Ez azt jelenti, hogy maga a vállalat magyar marad, viszont az adózás a szlovák rendszer alapján történik.

A szlovák reláció felé való nyitás másik fontos oka a piacbővítés lehetősége, hiszen a térhódítás és az új piacokra való behatolás a nagyobb árbevétel elérését kínálja a feltörekvő cégek számára. A terjeszkedés alapfeltétele az úgynevezett piacelemzés készitése. Az elemzés segítségével a vállalkozások számára alkalom nyilik egy elözetes keresletfelmérésre, amely alapján a vállalkozó el tudja dönteni, hogy érdemes-e az adott szektorba beruháznia. Ráadásul a határ menti bövítéssel a cégek tulajdonképpen magyar környezetbe kerülnek, mivel a határszakaszon szinte mindenki magyarul beszél. Ezt pedig tökéletesen kiegészíti a szlovák munkaerő kép- 
Grosz András - Tilinger Attila: A gazdasági szereplök határon átnyúló tevékenysége.

Tér és Társadalom, 22. 2008. 3. 81-96. p.

zettsége, megbízhatósága és olcsósága. A kilencvenes években 20-25\%-os munkanélküliség volt Szlovákiában, melynek jelentős részét mára többek között a magyar vállalkozók szívták fel. A pozsonyi térségben és Nyugat-Szlovákiában számos multinacionális vállalat - többek között nagy autógyár - jelent meg, ahol a cégek a beszállítók beszállítójává kívánnak válni. Ez a komoly autóipari súrủsödés a beszállítói kapcsolatok kiépítése szempontjából kap nagyobb hangsúlyt, a határnyitás pedig a kitelepüléshez ad komoly lehetöséget a magyar vállalkozások számára.

A Szlovákia felé történő gazdasági nyitásnak sajnos beszélhetünk egy negatív oldaláról is. A vállalkozóknak nagyon körültekintönek kell lenniük, mivel előfordulhat, hogy Magyarországon rossz szemmel nézik, ha egy üzleti tárgyaláson szlovák rendszámú autóval jelenik meg valaki. Ezzel más az image, az adott vállalkozóról a partnerek szemében kialakuló kép. De ez a negatív diszkrimináció a szlovák oldalon is ugyanúgy megtörténhet.

Összességében megállapíthatjuk, hogy Szlovákia gazdasága az utóbbi években rendkívül sokat fejlődött, de termelési és fogyasztási szintje még nem éri el hazánkét. Mivel a gazdaság múködési logikája a szomszédos Szlovákiában kedvezőbb feltételek mellett alakul, ezért számtalan magyar vállalkozó nyit a határ másik oldala felé. A két ország közötti piaci tevékenységek bővülése pedig a közös gazdasági fejlődést irányozza elő.

\section{A cégalapitás lehetöségei Magyarországon}

Az előzőekben a magyar vállalkozások szlovákiai terjeszkedését vizsgáltuk meg, ahol is arra a megállapításra jutottunk, hogy a hazai cégek számára a szlovák bővítés legnagyobb vonzóereje a kedvezőbb gazdasági környezet. Ha ez így van, akkor egy szlovák vállalkozásnak miért érdemes befektetnie Magyarországon? Vonzza-e a szlovák cégeket egy esetleges magyarországi bővítés lehetősége? Ha igen, akkor mi ennek az oka?

Igaz, a szomszédos országunkba irányuló mozgásoknak csak töredékét jelentik, de a szlovák cégek is próbálják gazdasági tevékenységeiket hazánkba kiterjeszteni. Ennek elsődleges magyarázata a piacbövítés igénye, ủj piacok megszerzése. A piac nagyobb méretéből adódóan jelentős felvevőpiacot jelent Magyarország, így a szlovák vállalkołások - azon termékek esetében, amelyek a magyar piacon is életképesek - a piaci rés kihasználására törekednek. Itt példaként megemlíthetjük, hogy a komáromi Vállalkozók Házában is múködnek szlovák tulajdonú vállalkozások, melyek a magyar piacot próbálják lefedni. A szlovák vállalkozások számára vonzó lehet az a tény is, hogy vásárlóeröben a magyar piac erősebb; hazánkban magasabb az árszínvonal, ezért nagyobb profit érhető el. A szlovák-magyar határszakasz északdunántúli részén könnyebben megfogható a piac, kedvezőbb, mint az ország keleti felében, hiszen Pozsony mellett a györi térség jelentős koncentrációt képvisel. A határ túloldaláról jellemzően a magyar anyanyelvủek jönnek át, mely a kapcsolatteremtésre is könnyebb lehetőséget biztosít. Mivel Magyarországon az észak-dunántúli térségben már egyre komolyabb a szakképzett munkaerỏ hiánya, a hazánkban letelepedett kül- 
Grosz András - Tilinger Attila: A gazdasági szereplök határon átnyúló tevékenysége.

Tér és Társadalom, 22. 2008. 3. 81-96. p.

földi vállalatok (pl. Nokia, Suzuki) tömegesen vonzzák a viszonylag olcsó szlovák munkaerőt. A munkaerő-közvetítő irodák szerepe e téren megkérdőjelezhetetlen. Ugyanakkor a nagyszámú határ menti ingázó tömeg ellenére nem jellemző, hogy szlovák vállalkozások telepednének hazánkba, melynek oka elsősorban a szlovák helyzettel összehasonlítva sokkal kevésbé vállalkozásbarát hazai környezet. A szlovák cégeknek maximum akkor éri meg hazánkba települniük, ha valamely Magyarországon müködő multinacionális vállalat beszállítójává tudnak válni, ugyanakkor egy cégnek ahhoz, hogy piacait bỏvítse, nincsen szükség új cég alapítására, hiszen a meglévő telephelyekről is elérhető a határ túloldala. Végül fel kell hívnunk arra a figyelmet, hogy a magyar területek felé való nyitás nemcsak a gyártásban jelenthet komparativ előnyöket, hanem a forrásszerzés szempontja sem zárható ki.

\section{Befektetési kedv, gazdasági mozgások}

Magyarországon kedvezőtlen a gazdasági környezet, a kis- és középvállalatok körében a befektetési kedv az utóbbi pár évben komolyan visszaesett. Ez csökkenti az ország tőkevonzó képességét, ami azt jelenti, hogy inkább a magyar vállalkozások mennek Szlovákiába, mint fordítva. De vajon mely folyamatok vezettek ehhez az állapothoz?

Az áfa 1988-as bevezetése óta évröl-évre csak bonyolultabb lett a magyar adórendszer. Az adózás módja rendkívül komplikált, átláthatatlan és sokszor káosz uralkodik a rendszerben. A hazai gazdasági környezet vállalkozási szinten vonzóvá tételéhez adóegyszerüsítés kellene, melyre a legalkalmasabb eszköz a szlovák egykulcsos rendszerhez hasonló bevezetése lenne. Az adóreformhoz viszont megtörhetetlen politikai akaratra lenne szükség. Szlovákia kormánya mindezt megvalósította, mely által vonzó és befektetőbarát lett az ország. Ennek elönyeit napjainkban is élvezik a szlovákok. Egyes vélemények szerint, mint arról már korábban szó volt, a két ország között egy 5-10 éves fáziseltolódás jelentkezik, és Szlovákiára még sokkal inkább az alacsonyabb hozzáadott értékú termelés a jellemző. A Szlovákiába érkező nagy külföldi befektetỏi boomnak pedig nem az alacsony, egykulcsos adórendszer az első számú hajtóereje, hanem az alacsony költségtényezők. Összességében a gazdasági környezet tekintetében jelenleg Magyarország mindenképpen hátrányosabb helyzetben van Szlovákiához képest.

Kutatásunk arra is kiterjedt, hogy a szlovák-magyar gazdasági kapcsolatok alakulásában voltak-e olyan mérföldkövek, amelyek jelentősebb változásokat okoztak a határtérség integrálódásában. Az elkészített interjúk alapján elmondhatjuk, hogy a két ország határtérségének fejlődése folyamatos, töretlen. Jelentősebb változást csak az európai unióhoz történő csatlakozás eredményezett. A két állam egyidejủleg lett tag, így ettől fogva a szomszédos országok állampolgárai korlátozás nélkül, szabadon ủzhetnek vállalkozási tevékenységet, illetve ami talán rövid és középtávon még fontosabb volt, azonnal megnyitották egymás előtt munkaerőpiacaikat. Az EUtagság tehát kiváló lehetőséget biztosít arra, hogy a szomszédos ország előnyeit maximálisan ki lehessen használni. Igaz, 2004 óta nincs vám, közvetlenebbé vált a 
Grosz András - Tilinger Attila: A gazdasági szereplök határon átnyúló tevékenysége.

Tér és Társadalom, 22. 2008. 3. 81-96. p.

kereskedés, ami könnyebbséget jelent a kereskedelemben, azonban egyröl a kettőre nem omlanak le a falak. Mivel korábban sem volt szigorú határellenörzés, a Schengeni Egyezményhez történő csatlakozás már nem érinti különösebben a szlovák-magyar határtérséget, esetleges hatását még nem lehet érezni.

A gazdasági mozgások szakadatlan erősödése figyelhető meg - az elöbb említett módon -, viszont a határ túloldalára befektetók száma így is kevés, tömeges áttelepülés nines és nem is volt. A térség eredeti tỏkefelhalmozása most zajlik, ami azt jelenti, hogy nem áll elegendỏ pénz a vállalkozások rendelkezésére. A szlovák-magyar tỏke nem versenyképes, nincsenek dömpingszerü beruházások. De amint megerősödnek a kis- és középvállalkozások, egyre több külföldi tőkeinvesztíció lesz. Napjainkban viszont a kedvező szlovák gazdasági környezet hatására ezek a mozgások inkább - Szlovákia felé - egyirányúak. Jelenleg magyar állampolgárok cégalapításával és autóvásárlásával közel harminc szlovák cég foglalkozik, jellemzően a határ menti régiókban, Pozsonytól egészen Kassáig. Cégalapitástól autóbérlésig mindenre kész megoldásokat kínálnak, sőt olykor-olykor egymásra is licitálnak.

Annak ellenére, hogy a magyar-szlovák kapcoslatokban tradicionálisan jelen vannak a politikai életben tapasztalható negatív folyamatok, köszönhetően annak, hogy Szlovákia és Magyarország is rendkívül nyitott gazdaság, a konkrét gazdasági kapcsolatokra ezen politikai fejlemények csak korlátozottan és közvetetten képesek hatni. A gazdasági szféra jóval rugalmasabb a politikánál, a cégek a vállalati nyereség és az üzleti érdek alapján mozognak. A két ország közötti feszült állapot minimális szintú visszatartó ereje elsősorban mikro- és kisvállalkozási szinten jelentkezik, nagyvállalatok szintjén nem.

\section{Határon átnyúló gazdasági kapcsolatok}

A következökben elsősorban azt szeretnénk bemutatni, hogy milyen kapcsolatok jellemzik egyfelől a határ menti térségben müködő gazdaságfejlesztési, vállalkozásfejlesztési szervezeteket, másfelöl pedig magukat a vállalkozásokat. Milyen területeken mủködnek a határ egyik oldaláról a másikon gründolt vállalkozások, milyen problémákkal szembesülnek, és milyen területeken várnak segítséget?

\section{Az intézmények kapcsolatrendszere}

A következőkben a kutatásunkba bevont szervezeteket vállalati kapcsolatrendszerükön keresztül vizsgáljuk meg, azaz konkrétan ismernek-e, vagy kapcsolatban vannak-e olyan magyar vállalkozásokkal, amelyek szlovák telephelyek iránt érdeklődnek, illetve magyar telephelyek iránt érdeklődnek-e szlovák vállalkozások. A felkeresett intézmények jelentős része kapesolatban van hasonló cégekkel, azonban a vállalkozások többsége magyar, akik szlovák vállalkozást alapítanak, forditva csak jóval kisebb számban fordulnak elő. Ezek alapján tehát elmondható, hogy a szlovák érdeklődés nagyon gyenge, és a kedvezőbb adózási feltételek végett érthető módon a magyar érdeklődők vannak túlsúlyban. 
Grosz András - Tilinger Attila: A gazdasági szereplök határon átnyúló tevékenysége.

Tér és Társadalom, 22. 2008. 3. 81-96. p.

Nem véletlen, hogy a nyugati határ mentén a külföld felé nyitni szándékozó vállalkozók kamarai megkeresései elsósorban Ausztria irányába jellemzőek, ugyanakkor már megfigyelhetö, hogy főként új cég-, leányvállalat alapítása, telephelyáttétel, vegyes vállalkozás létrehozása és kooperációs partner keresése ügyében Szlovákia iránt is egyre élénkebb az érdeklödés. A szlovák megkeresések száma ezzel szemben nem túl jelentős, hisz ök inkább a saját kamaráikon keresztül intézik ügyeiket, és Magyarországra telepedéskor már minden kapesolódó tudás birtokában vannak, amelyekre már az elózetes helyzetfelmérések és -elemzések során szert tesznek. A hazai kamarákkal elsősorban együttmüködési partnerek keresése, mint egyfajta határon átnyúló szolgáltatás érdekében lépnek kapcsolatba.

A vállalati után a szervezetek intézményi - azaz valamely szlovák kereskedelmi és iparkamarával, vállalkozásfejlesztési alapítvánnyal, egyéb gazdasági társaságokat menedzselő szervezettel, önkormányzattal, regionális szervezettel, intézménnyel való - kapcsolatrendszerét vettük górcsỏ alá.

A gazdasági kamarák számos intézménnyel ápolnak kifejezetten jó kapcsolatot. A legfontosabb együttmüködő partnereik elsősorban a szlovák gazdasági kamarák (pl. pozsonyi, nyitrai). Ezek a kapcsolatok az általános jellegủ szakmai találkozóktól kezdve, a célirányos vállalkozói partnerközvetítésen keresztül a közös projektek megvalósításáig rendkívül szerteágazóak. Ilyen közös projektre lepet példa a Komárom-Esztergom megyei és a nyitrai kamarák közös Interreg III/C projektje a határ menti együttmüködések elősegítése érdekében, mely során egy régiós Befektetői Kézikönyv is született, vagy a Komárom-Esztergom megyei, a Heves megyei, a Nógrád megyei kereskedelmi és iparkamarák és a Besztercebányai regionális gazdasági kamara egyưttmúködése a regionális üzleti- és beszállítói hálózatfejlesztés és közös gépipari klaszteresedés elősegítése érdekében (Cégkatalógus... 2005). A gazdasági kamarák mellett természetesen más intézményekkel és szervezetekkel is kapcsolatban állnak, így vállalkozásfejlesztési alapítványokkal, szakképzési intézményekkel, az ITDH pozsonyi kirendeltségével, a Magyar-Szlovák Tagozattal, vagy hazánkban a Szlovák Köztársaság Magyar Nagykövetségével. Számos közös határon átnyúló projektet (Interreg és Phare CBC) valósítottak meg a vállalkozásfejlesztési alapítványok és a hasonló tevékenységet végző szlovák szervezetek is (pl. Kisalföld Vállalkozásfejlesztési Alapítvány és a regionális tanácsadó és információs központok együttmúködése). Még szorosabbak az intézményi együttmüködések a közvetlen határ menti szervezetek esetében, ahol sokszor személyes kapcsolatok is erősítik azokat (pl. Komáromi Vállalkozók Háza és az észak- és dél-komáromi Vállalkozásfejlesztési Alapítvány). A felsőoktatási szférában ugyanakkkor egyelőre jóval mérsékeltebb a határon átnyúló együttmúködések intenzitása. Elsősorban a személyes oktatói kapcsolatok a jellmezöek és a hallgatócsere, míg a kutatásfejlesztés vagy az oktatás terén a kooperáció nem nevezhetó jelentősnek. 
Grosz András - Tilinger Attila: A gazdasági szereplök határon átnyúló tevékenysége.

Tér és Társadalom, 22. 2008. 3. 81-96. p.

\section{A Magyarországon müködő szlovák gazdasági társaságok}

A vizsgálat során készített interjúk alapján azt mondhatjuk, hogy a Magyarországon mủködő szlovákiai gazdasági társaságok jellemzően a kereskedelem területén vannak jelen. Ezen kívül tipikus területek még a szolgáltatás, az információs technológia és az üzleti partnerközvetítés, de a gépipari cégek jelenléte is domináns. A hazánkban tevékenykedö gazdasági társaságok elsősorban vegyes vállalkozások. A foglalkoztatottakat tekintve, nyílván a kitủnő helyismeret végett magyar munkaerőt is alkalmaznak, de különösen a határhoz közeli térségben meghatározó a szlovákiai foglalkoztatottak aránya (pl. egy szlovák tulajdonban lévő esztergomi szállodában a személyzet szlovák állampolgár).

A szlovák vállalatok magyarországi kapcsolatait számos tényezö befolyásolja. A kooperációkészség többek között függ az adott vállalattól, a menedzsment szemléletétől, a cég küldetésétől, valamint a piaci stratégiától. A szlovák vállalkozások helyismerethiánya két szélsőséges lehetőséget szül: az adott cég vagy teljesen elzárkózik a külvilágtól, vagy fokozottan a kapcsolatokat keresi. A szlovák cégek hazánkban leggyakrabban igénybevett szolgáltatásai közé tartozik a partnerkeresés, tanácsadás, tájékoztató rendezvényeken való részvétel, kiállítás látogatás, üzletember találkozó, alapítással kapcsolatos egyéb szolgáltatások, ügyvédi tevékenység, valamint székhely/telephely biztosítás. A piacaikkal kapcsolatos információkat a cégek jellemzően önállóan, maguk gyüjtik össze.

$\mathrm{Az}$ észak-dunántúli térség Magyarországon letelepedett szlovák vállalataira jellemzö, hogy szervezett formában általában nem mủködnek együtt a kamarákkal. A cégek nem veszik igénybe a kamarák segítségét, ezen intézmények szerepe csupán az információnyújtás erejéig terjed (pl. a Györ-Moson-Sopron Megyei Kereskedelmi és Iparkamarát egy szlovák termékforgalmazó cég kereste fel a hazánkban dolgozó alkalmazottak képzésének segítésével kapcsolatban). A megkeresések nagy része adójogi vagy egyéb, elsősorban a mindennapos múködéssel kapcsolatos információkra irányul. Speciális esetekben az adott vállalkozásokat célirányosan más szervezetekhez irányítják. A kooperációnak különösebb akadálya - nyelvi korlátja nincs, mivel a kamarában többek között angolul, németül és franciául is beszélnek. Mindezek ellenére a győri kamaránál szlovák megkeresések nem jellemzőek. Hasonló a helyzet a Komárom-Esztergom Megyei Kereskedelmi és Iparkamaránál is. A kamara és a cégek között gyenge a kapcsolat, mivel a kamarára nincs igazán szükségük. Az infrastruktúrát, a szakember-szükségletet a vállalkozások képesek saját maguk megoldani. Az intézmény által nyújtott szolgáltatások közül a legnépszerübb a különféle rendezvényeken való részvétel.

Konkrét vállalati kapcsolatról nem csak a kamarák, de a Kisalföld Vállalkozásfejlesztési Alapítvány sem tud beszámolni. A cégek csupán érdeklődés szintjén tárgyalnak az alapítvánnyal. A vállalatok jellemzően három fỏ területen veszik igénybe az intézmény segítségét: a magyarországi gazdasági helyzet felmérésére, partnercég keresésre, valamint a hazai támogatási rendszerről való informálódásra. Ezen kívül az alapítvány szolgáltatásai közé tartozik a szlovákiai partnerkeresés, 
Grosz András - Tilinger Attila: A gazdasági szereplök határon átnyúló tevékenysége.

Tér és Társadalom, 22. 2008. 3. 81-96. p.

ami a piacra jutást segíti. Az alapítvány-cég együttmúködést akadályozó tényezöként lehet említeni, hogy a vállalkozások sokszor más csatornákon szerzik be az információt, például ügyvédi irodákon keresztül.

A komáromi Vállalkozók Házába Szlovákiából jellemzően a szlovák alapítók magyarországi cégei települtek. Az intézmény-cég kapcsolatot itt csak az ingatlan hasznosítás, bérlés, valamint eseti tanácsadás jellemzi, akadályozó tényező nincs. A cégek számára a Vállalkozók Háza közkedvelt telephely, mivel a bérleti díj a piaci árnál alacsonyabb, a szolgáltatása pedig az átlagosnál bóvebb.

\section{A Szlovákiában müködö magyar gazdasági társaságok}

A Szlovákiában múködő magyar cégek jellemzỏen a kereskedelem (pl. szállitmányozás), szolgáltatás (pl. karbantartás, javitás, ipari takaritás), vendéglátás, ipari tevékenység területeken müködnek. De gyakran elöfordul, hogy a Szlovákiában letelepedett multinacionális autógyártó cégek beszállítóinak beszállítóivá kívánnak válni. Általánosságban elmondható, hogy a gazdasági társaságok ügyvezetöje magyar, a vállalkozótársa viszont gyakran szlovák nemzetiségú. Alkalmazottként jellemzöen szlovákiai munkaeröt foglalkoztatnak. Mivel kevés magyar beszél szlovákul, ezért nagyrészt szlovákiai magyart, illetve a helyi viszonyokat, helyi piacokat jól ismerő szlovák állampolgárt keresnek.

A szlovákiai magyar vállalkozások múködését elsősorban a szlovák kereskedelmi és iparkamarák, vállalkozásfejlesztési alapítványok és hasonló szervezetek tudják leginkább segiteni. Ennek ellenére a Györ-Moson-Sopron Megyei Kereskedelmi és Iparkamara több ilyen céggel is napi kapcsolatban van. A Kamarát leggyakrabban cégalapítás, határon átnyúló szolgáltatás, információ, tájékoztatás, múködéssel kapcsolatos, jogi-, adójogi kérdések, adózási szabályok, könyvelö-, ügyvéd-, adótanácsadó biztosítás témakörben keresik fel. A kereskedelmi képviselettel, illetve kirendeltséggel kapcsolatba lép a Kamara, a vitás ügyekben pedig segítséget nyújt. Ezzel szemben a Komárom-Esztergom Megyei Kereskedelmi és Iparkamarára nem jellemző a Szlovákiában müködő gazdasági társaságokkal való kapcsolat. Viszont a györi Kisalföld Vállalkozásfejlesztési Alapítványnak ugyancsak van kapcsolata hasonló cégekkel. Az Alapítvány szerint általában az a jellemző ezekre a társaságokra, hogy megmarad a magyar anyacég, és kapcsolt vállalkozásként müködnek tovább Szlovákiában. Az alapítvány-vállalat konzultáció legtöbbször a szlovákmagyar viszony összehasonlításában és a pályázati kérdésekben merül ki. Habár ezek a vállalkozások a magyar intézmények szolgáltatásait kevésbé veszik igénybe, hátországi visszacsatolásra mindig szükség van.

A kamara-cég együttmüködést akadályozó tényezőként léphet fel a győri Kamara mérete. Az intézmény kicsi, kevés az ember, nincs megfelelő kapacitás, a szlovák környezetet ezért nem nagyon ismerik. A vállalkozások éppen ezért inkább a szlovák kamarákkal lépnek kapcsolatba. A Komárom-Esztergom Megyei Kamara szerint viszont az együttmüködések legnagyobb hátráltató tényezöje az információhiány. A cégek nem elég informáltak a kamarák szolgáltatásairól, így nem is nagyon veszik 
Grosz András - Tilinger Attila: A gazdasági szereplök határon átnyúló tevékenysége.

Tér és Társadalom, 22. 2008. 3. 81-96. p.

igénybe azokat. Ebben a földrajzi távolság is közrejátszhat, példaként említve a nyitrai Kamarát, ami a határtól meglehetősen távol helyezkedik el, a vállalatok zöme pedig 20-30 km-en belül van a határhoz. Mindezeken túl a győri székhelyü Kisalföld Vállalkozásfejlesztési Alapítvány a szlovák szervezetek szakmai lemaradására hivatkozik. Bár az európai uniós programokat ismerik ezek az intézmények, a szakmai hozzáértés kevésbé van meg, hiányzik a szervezetek közötti összhang, mert később kezdték a tevékenységüket. Nyelvi korlát nincs, szinte mindenki beszél magyarul.

\section{Intézményi-vállalati szintü fejlesztések}

Intézményi és vállalati szinten egyaránt az integrálódási folyamat elősegitéséhez szükséges fejlesztéseknek mindenképpen van realitása. Az európai uniós tagállami együttműködés és fejlődés csak előremenekülve lehetséges. A két ország között nem csak a hosszú közös határszakasz miatt, hanem a nemzetiségi hovatartozás végett is speciális kapcsolat van.

Az intézményi fejlesztés területén a rendszeresen ülésező kormányközi bizottság/testület hatékony működése teremthetne lehetőséget az elörehaladás kérdéseinek folyamatos vizsgálatára. Határ menti együttmüködésre jelenleg is vannak példák, azonban ezek nem szervezett és nem összefogott kezdeményezések. Az integrálódást nemcsak kutatóhelyek, innovációs centrumok együttmúködésének ösztönzése, hanem klaszterek kialakítása is segítheti. A fejlesztések optimális összehangolása érdekében elkerülhetetlen vegyes kereskedelmi és iparkamarák alakítása. Az intézményrendszer minél magasabb szinten való kiépítettsége pedig a vállalatok kooperatív magatartását ösztönzi.

A gazdasági szereplők számára a vállalkozói partnerinformáció értéke felbecsülhetetlen. A közvetlen kapcsolat, az első kézböl kapott tudás a 21. század globalizálódott világában egy vállalkozás müködésének alapkelléke. A cégek tevékenységét segitő intézmények mindehhez információs napok, rendezvények, tájékoztatók szervezésével tudnak leghatékonyabban hozzájárulni. A megfelelö információhoz való jutás elősegitésére kitủnő példát találunk: a határ mindkét oldalán olyan adatbázis kiépítésére került sor, amely a vállalatok számára hasznos információkat tartalmazott, többek között a törvényi elörrásokat és a támogatási rendszert; az adatbázisokat pedig egymás rendelkezésre bocsátották. Itt azonban egy óriási problémával kell szembesülnünk. Az összeállított adatbázis tartalma nem statikus, hanem dinamikus, azaz folyamatosan változik. Pénz pedig csak az információk egyszeri összegyüjtésére volt. A friss, naprakész információk megszerzéséhez új projektre lenne szükség. A folyamatos nyomon követés elengedhetetlen, a vállalkozók azonban az ilyen jellegủ szolgáltatásokért nem fizetnek. A megfelelően kvalifikált szakembergárda és az adatbázis önmagában nem elegendő, a vállalatoknak tudniuk kell erröl a lehetöségröl, a médiában meg kell jelentetni, reklámozni kell, viszont ez sem ingyenes, pénzügyi forrás, anyagi támogatás kell hozzá. 
Grosz András - Tilinger Attila: A gazdasági szereplök határon átnyúló tevékenysége.

Tér és Társadalom, 22. 2008. 3. 81-96. p.

Az információ egymaga nem elégséges, a kis- és középvállalatokat jellemző bizalomhiányt is oldani kell. Olyan közös tréningekre van szükség, ahol fizikailag össze vannak zárva a vállalkozók. Ez az egyedi élményen keresztül való kapcsolatépítés a közös élményen keresztüli nyitottság irányába terelné a cégeket. A közös szlovákmagyar projektek leggyakoribb hibája, hogy mindkét oldalon mindkét cég különkülön valósít meg egy-egy projektet, az együttműködés csupán a beszámoló erejéig terjed. Éppen ezért közös fejlesztéssel járó projektek véghezvitelére lenne szükség, nem kizárva az ipar és a környezetvédelem területén megvalósítandó határ menti nagyprojekteket sem.

Egyes vélemények szerint hosszú távon az Európai Unió fejlódésével nemcsak a vizsgálatunkba bevont Szlovákia és Magyarország között nivellálódnak a különbségek, hanem a magyar-nyugati színvonal is kiegyenlítődik. Bár a hétköznapi ember a bérszínvonal felzárkózásának tulajdonítja a legnagyobb jelentőséget, az országok szabályozása (pl. adórendszer) közötti különbségek kiegyenlítődése is legalább akkora fontosságú. Tehát mivel az egyes országok között csak minimális különbségek lesznek, a határtérségben nem lesz szükség akkora mozgásokra, a kapcsolatok intenzitása csökkeni fog.

Végül, de nem utolsósorban meg kell említenünk, hogy az intézményi és vállalati szintü fejlesztéseknek csak akkor van jövöje, ha a két ország gazdasági szereplöi felismerik a közös egyutttmüködési pontokat, érdekeket, és ha egy közös cél érdekében együtt tudnak dolgozni.

\section{Irodalom}

A határ menti vállalkozások humánerőforrás ellátottsága és -gazdálkodása. (2006) Kisalföld Vállalkozásfejlesztési Alapítvány, Győr.

Ádám J.I. (2003) A magyar-szlovák gazdasági kapcsolatok fejlődési lehetőségei az EU-csatlakozás tiukrében. - Réti T. (szerk.) A gazdasági integráció esélyei Szerbia és Szlovákia határ menti régióiban. Európai Összehasonlító Kisebbségkutatások Közalapítvány, Budapest. 27-34. o.

Ádám J.I. (2004) A határon túli magyarok részvétele a gazdasági átalakulásban - Szlovákia. -- Réti T. (szerk.) Közeledó régiók a Kárpát-medencében: Dél-Szlovákia, Erdély és a Vajdaság gazdasági átalakulása. I. kötet. Európai Összehasonlító Kisebbségkutatások Közalapítvány, Budapest. 267-302. 0.

Ádám J.I. (2005) A dél-szlovákiai régió fejlődése a helyi kezdeményezések és a határon átnyúló együttmüködések tükrében. - Réti T. (szerk.) Közeledó régiók a Kárpát-medencében: Dél-Szlovákia, Erdély és a Vajdaság gazdasági átalakulása. II. kötet. Európai Összehasonlító Kisebbségkutatások Közalapítvány, Budapest. 21-58. 0 .

Balogh Cs.-Gulyás L.-Nagy Zs. (2004) Ipari terek és vállalkozások. - Horváth Gy. (szerk.) DélSzlovákia. A Kárpát-medence régiói 2. MTA Regionális Kutatások Központja-Dialóg Campus, PécsBudapest. 326-352. o.

Beluszky P. (szerk.) (2007) Közép-Magyarország. A Kárpát-medence régiỏi 6. MTA Regionális Kutatások Központja-Dialóg Campus, Pécs-Budapest.

Cégkatalógus. Maguar-szlovák gépipari kaszter. (2005) Heves Megyei Kereskedelmi és Iparkamara, Eger.

Gyốr-Moson-Sopron megyében és a Dunaszerdahelyi járásban müködö vállalkozások együttmüködési programja. (2000) Kisalföld Vảllalkozásfejlesztési Alapítvány, Györ.

Helyzetkép a határ menti vállalkozások gazdálkodásáról, forrásszerzési lehetóségeiről. (2006) Kisalföld Vállalkozásfejlesztési Alapítvăny, Györ.

Horváth Gy. (szerk.) (2004) Dél-Szlovákia. A Kárpát-medence régiói 2. MTA Regionális Kutatások Központja-Dialóg Campus, Pécs-Budapest. 
Grosz András - Tilinger Attila: A gazdasági szereplök határon átnyúló tevékenysége.

Tér és Társadalom, 22. 2008. 3. 81-96. p.

Lelkes G. (2003) Elmaradottság és versenyképességi elemek a dél-szlovákiai térben. - Fórum: Társadalomtudományi Szemle. 4. 3-18. o.

Lelkes G. (2005) Dél-Szlovákia gazdasági fejlódése és a határon átnyúló kapcsolatok. - Fórum: Társadalomtudományi Szemle. 1. 143-144. o.

Lelkes G. (2008) Régiók és gazdaság. Lilium Aurum Kiadó, Forum Intézet, Somorja.

Lelkes G. -Szalay Z. (2004) Népesség, munkerőpiac. - Horváth Gy. (szerk.) Dél-Szlovákia. A Kárpátmedence régiói 2. MTA Regionális Kutatások Központja-Dialóg Campus, Pécs-Budapest. 237-270. o.

Mézes Zs.L. (2006) A külföldiek munkavállalása Magyarországon. Európai Összehasonlító Kisebbségkutatások Közalapítvány, Budapest.

Morvay K. (2004) A külföldi tőkebefektetések és az ipari parkok Dél-Szlovákiában. - Réti T. (szerk.) Közeledö régiók a Kárpát-medencében: Dél-Szlovákia, Erdély és a Vajdaság gazdasági átalakulása. I. kötet. Európai Összehasonlitó Kisebbségkutatások Közalapítvány, Budapest. 303-330. o.

Rechnitzer J. (szerk.) (2007) Nyugat-Dunántúl. A Kárpát-medence régiói 5. MTA Regionális Kutatások Központja-Dialóg Campus, Pécs-Budapest.

Rechnitzer J.-Smahó M. (2006) Regionális politika. Egyetemi jegyzet. Széchenyi István Egyetem, Györ.

Reiter F.-Semsey I.-Tóth A. (2004) Kelet-Szlovákia régió gazdasági átalakulása. - Réti T. (szerk.) Közeledö régiók a Kárpát-medencében: Dél-Szlovákia, Erdély és a Vajdaság gazdasági átalakulảsa. I. kötet. Európai Összehasonlító Kisebbségkutatások Közalapítvány, Budapest. 331-362. o.

Réti T. (1999) Magyar tỏkekivitel Romániảba és Szlovákiába. - Külgazdaság. 11. 27-47. o.

Réti T. (szerk.) (2003) A gazdasági integráció esélyei Szerbia és Szlovákia határ menti régióiban. Európai Összehasonlító Kisebbségkutatások Közalapitvány, Budapest.

Réti T. (szerk.) (2004a) Átalakuló régiók: Dél-Szlovákia és a magyarok által lakott régiók gazdasági helyzete. Európai Összehasonlító Kisebbségkutatások Közalapítvány, Budapest.

Réti T. (szerk.) (2004b) Közeledö régiók a Kárpát-medencében: Dél-Szlovákia, Erdély és a Vajdasảg gazdasági átalakulása. I. kötet. Európai Összehasonlító Kisebbségkutatások Közalapítvány, Budapest.

Réti T. (szerk.) (2005) Közeledö régiók a Kárpát-medencében: Dél-Szlovákia, Erdély és a Vajdaság gazdasági átalakulása. II. kötet. Európai Összehasonlító Kisebbségkutatások Közalapítvány, Budapest.

Új csodafegyvere van a szlovák gazdaságnak. (2008) - FigyelöNet. Március 4.

Tornay I. (2004) Európai Detroit? - Heti Válasz. 27.

\section{CROSS-BORDER ACTIVITIES IN BUSINESS}

\section{ANDRÁS GROSZ - ATTILA TILINGER}

The most important aim of the study is the exploration of the Slovak-Hungarian crossborder interactions of economic actors. Out of the cross-border regional differences and the economic development based on the foreign direct investments, the opportunity of firm's establishment in the neighbour countries is also a subject of the analysis. The authors study the measure and deepness of the cooperation between institutional-economic actors, and try to find the extent of the integration process among the two sides of the border region. Finally the study enlightens that the continuous growth of the investments reflects on the vivification of the economic movements, of which are intensified by the institutional- and corporate-level developments. EU membership in 2004 was a significant milestone in cross-border cooperation, while the accession to Schengen treaty did not brought perceptible changes. In the future the introduction of the euro, especially the time difference between the two countries regarding to the introduction has serious effects on the integration processes. 